\title{
BELAJAR ALGORITMA PEMROGRAMAN UNTUK INFORMATIKA
}

\author{
Oleh : Pinta Riski Barokah \\ PMM FITK UINSU \\ Barokahpintariski@gmail.com
}

\begin{abstract}
ABSTRAK
Algoritma merupakan pusat dari informatika atau ilmu komputer. Tidak sedikit cabang-cabang ilmu komputer mengarah ke istilah algoritma. Tidak lupa juga bahwa algoritma bukan hanya selalu membicarakan tentang ilmu komputer atau informatika saja. Pada aktivitas yang kita jalani sehari-hari di dalamnya juga tidak sedikit proses yang diekspresikan dalam suatu algoritma. "Algoritma adalah urutan langkah-langkah logis untuk memecahkan masalah yang disusun secara sistematis dan logis". Dalam algoritma ada beberapa kata kunci salah satunya yaitu Kata logis. Semua proses langkah demi langkah dalam algoritma wajib logis dan harus betul-betul dinyatakan layak ataupun benarnya. Di tarik dari beberapa pengertian, algoritma adalah perincian dari jajaran langkah demi langkah dalam pelaksanaan suatu aktivitas tertentu. Seluruh pemberitahuan dalam komputer di sebut program, algoritma juga termasuk teknik dan prosedur secara terurut dan baik dalam program. Penulisan program dilakukan dengan penggunaan bahasa pemrograman. Maka dapat di simpulkan dari bahasa pemrograman dapat di implementasikan suatu program.
\end{abstract}

KATA KUNCI : Algoritna , Informatika , Ilmu komputer , Logis , Program

\section{Pendahuluan}

Dilihat dari keunikan sejarah pencarian asal kata algoritm, beberapa ahli menemukan kata algorism saja, kata algorism sendiri mengandung arti yaitu proses berhitung dengan angka arab. Seseorang yang melakukan suatu proses menghitung dengan penggunaan angka arab di sebut algorist. Beberapa ahli mencoba mencari asal kata algoritma ini tetapi mereka tidak terpuaskan dengan hasil akhirnya.
Pencarian asal kata algoritma ini di selesaikan dengan penemuan asal kata yang di ketahui asalnya dari pengarang kitab Abu Ja'far Muhammad Al-khuarizmi yang terkenal pada masanya. Para bangsa barat membaca Al-Khuwarizmi sebagai Algorism. Al-Jabar Wal-Muqabala"The book of restoration and reduction" yang mengandung arti "Kitab pemugaran dan pengurangan" merupakan judul buku yang di tulis oleh Al-Khuwarizmi, "Aljabar" (Algebra) merupakan suatu kata dasar yang di ambil dari judul buku tersebut. kata 
algorism berubah menjadi kata algorithm dikarenakan algorism sering dikacaukan dengan kata arithmetic,

Jadi perubahan akhiran -sm menjadi -thm, Disebabkan oleh lumrahnya perhitungan menggunakan angka arab, lama kelamaan algoritma secara bertahap digunakan dalam umum sebagai teknik perhitungan, hingga hilangnya makna asli tersebut. Kata algoritma sendiri merupakan hasil serapan dari kata algorithm Dalam bahasa Indonesia.

"Algoritma adalah urutan langkah logis dari solusi

masalah yang disusun secara sistematis dan logis". Algoritma, di dalamnya terdapat Kata logis sebagai kata kunci. Pada algoritma di haruskan step by step yg di kerjakan itu logis dan wajib dapat dibuktikan kebenaran juga kesalahannya. Ditarik dari beberapa pengertian, algoritma adalah jajaran dari urutan step by step dalam pelaksanaan suatu aktivitas tertentu. Pembandingan untuk pememilihan suatu algoritma yaitu, pertama, dalam algoritma tersebut tertanam sifat benar, dengan ini dinyatakan algoritma akan mengeluarkan keluaran yang diinginkan sesuai dengan jumlah masukan yang dikeluarkan. Tak masalah seberapa bagus algoritmanya, jika memberikan output yang salah, algoritma itu pasti tidak algoritma yg baik.

Pembandingan kedua yang wajib di teliti yaitu apakah sudah baik hasil yang di capai algoritma, itu merupakan hal penting untuk penyelesaian masalah yang di perlukan hasil perkiraan (results that only appraisal)dalam algoritma. Jika hasil yang di berikan hampir sama dengan nilai sebenarnya maka akan tercipta Algoritma yang baik. Yang Ketiga yaitu kemampuan algoritma. Kemampuan algoritma bisa dilihat melalui dua kategori yang berupa ketepatan waktu dan memori. Walaupun yang dihasilkan algoritma berupa output yang benar (sangat dekat), namun ketika kita harus meluangkan waktu berjam-jam untuk menghasilkan output, kemungkinan besar atau biasanya tidak akan menggunakan algoritma, kecepatan menghasilkan output merupakan hal yang di idamkan semua orang, sama halnya memori, ketika bertambah banyaknya penggunaan memori, maka bertambah buruk pula algoritmanya. Pada dasarnya semua orang mampu menciptakan algoritma yang beragam agar mampu melakukan berbagai penyelesaian masalah, meskipun terdapat beberapa perbedaan pada penyusunan algoritm tersebut, pastinya kita berharap menghasilkan output yang serupa. Oleh karena itu, pilihlah penggunaan algoritma yang paling cepat dan efisien. Seluruh perintah-perintah dalam komputer di sebut program, sedangkan algoritma adalah teknik dan langkah-langkah yang terurut pada suatu program. Penulisan program di laksanakan sesuai dengan penggunaan bahasa pemrograman. Sehingga dapat dikatakan implementasi dari suatu bahasa pemrograman merupakan suatu program. Wirth (1997) dalam bukunya terdapat suatu pernyataan menyatakan :

\section{Algoritma + Struktur Data $=$ Program}

Namun, algoritma dan susunan /struktur data berhubungan erat dengan suatu program. Baik buruknya suatu program di landasi dengan pemilihan struktur data dan algorima yang tepat, begitu pun sebaliknya.

\section{Metode}

"Algoritma adalah metode khusus untuk memecahkan suatu masalah" (Abu Ja'far Muhammad Ibn Musa Al Khawarizmi).

"Algoritma adalah urutan terbatas dari operasi yang terdefinisi dengan baik, yang masing-masing membutuhkan jumlah memori dan waktu yang terbatas untuk 
memecahkan masalah" (Goodman Hedet Niemi).

"Algoritme adalah seperangkat aturan terbatas yang menyediakan serangkaian operasi untuk memecahkan jenis masalah tertentu" (Donald E. Knuth).

"Algoritma adalah urutan langkahlangkah logis untuk memecahkan masalah yang disusun secara sistematis" (Rinaldi Munir).

"Algoritme adalah daftar langkah demi langkah terbatas dari instruksi yang didefinisikan dengan jelas yang digunakan untuk masalah tertentu" (Seymour Lipschutz, Ph.D. dan Marc Lipson, Ph.D.).

"Algoritma adalah deskripsi prosedur yang berakhir dengan hasil" (David Bolton).

"Algoritma adalah seperangkat aturan yang secara tepat mendefinisikan urutan operasi sedemikian rupa sehingga setiap aturan efektif jelas sehingga urutan berakhir dalam waktu yang terbatas" (Stone dan Knuth)

"Algoritme adalah seperangkat aturan yang memberi tahu kita dari waktu ke waktu dengan tepat bagaimana harus bertindak" (Minsky).

"Program adalah suatu kata, ekspresi, atau pernyataan yang disusun dan dirangkai menjadi suatu kesatuan prosedur, berupa urutan langkah-langkah, untuk memecahkan suatu masalah yang diimplementasikan dengan menggunakan bahasa pemrograman sehingga dapat dieksekusi oleh komputer". (Sukrisno).

"Program adalah urutan instruksi untuk menjalankan suatu komputasi" (Anwar Harjono).

"Program adalah sekumpulan instruksi yang diwujudkan dalam bentuk bahasa, kode skema, atau bentuk lain, yang bila digabungkan dengan media yang dapat dibaca oleh komputer akan dapat membuat komputer tersebut bekerja untuk melakukan fungsi-fungsi khusus, antara lain: persiapan dalam merancang petunjuk ini” (Sunarto).
"Program adalah sekelompok pernyataan yang tepat dan berurutan yang tujuannya adalah untuk memberi tahu komputer bagaimana melakukan sesuatu" (Sindhunata).

"Program sebagai aplikasi hasil analisis pemecahan masalah dibuat dalam bentuk program komputer" (Agoeng Widyatmoko).

"Program adalah aplikasi yang dibuat dengan menggunakan bahasa pemrograman tertentu dan telah diinstal pada komputer" (Janner Simarmata).

Ada banyak keuntungan dalam membuat algoritma, antara lain:

1. Penciptaan/penulisan algoritma langsung secara otomatis bahasanya di implementasikan oleh komputer, artinya pembuatannya tidak bergantung pada bahasa pemrograman apapun.

2. Seluruh notasi algoritma bisa ditransformasikan pada berbagai bahasa pemrograman.

3. Bagaimanapun jenis bahasa pemrograman itu akan tetap menghasilkan output yang sama di karenakan algoritmanya sama.

Berikut poin-poin penting yang harus di simak ketika pembuatan algoritma :

- Naskah algoritme memuat gambaran urutan prosedur penyelesaian/penanganan suatu masalah. Gambaran/deskripsi bisa di muat pada notasi apa pun asalkan mudah dipahami dan dimengerti.

- Di dalam naskah algoritmik tidak memuat notasi baku baik itu bahasa pemrograman, melainkan yang di pergunakan dalam pembuatan naskahnya berupa notasi algoritmik.

- Semua orang bisa menciptakan aturan penulisan dan notasi algoritmiknya sendiri, ketetapan ini 
di sebabkan karena teks algoritma tidak sama dengan teks program. Walaupun demikian, notasi algoritmik yang dibuat hendaknya sesuai dengan notasi bahasa pemrograman pada umumnya agar memudahkan kita nantinya dalam penerjemahan ke dalam bahasa pemrograman.

- Notasi algoritma bukanlah notasi bahasa pemrograman, oleh karena itu pseudocode dalam notasi algoritma tidak dapat dieksekusi oleh komputer. Agar dapat dieksekusi oleh komputer, pseudocode pada notasi algoritmik hendaknya diterjemahkan ke dalam notasi bahasa pemrograman yang telah di pilih sebelumnya. Ingatla setiap orang atau si penulis suatu program akan berhubungan erat /terkait pada aturan tata bahasa mereka sendiri dan spesifikasi mesin yang menjalankannya.

- Suatu masalah dalam pengubahan suatu bahasa ke dalam bahasa pemrograman akan terselesaikan karena kita bisa di bantu oleh algoritma.

- Algoritma juga termasuk salah satu hasil dari cara berpikir konseptual, agar bisa diimplementasikan pada komputer, suatu algoritma terlebih dahulu harus di terjemahkan ke dalam notasi bahasa pemrograman.

Untuk dapat diterjemahkan ke dalam bahasa pemrograman, terlebih dahulu simak beberapa hal berikut :

- Deklarasi variabel dalam bahasa pemrograman ketika ingin menggunakannya maka sangat di butuhkan deklarasi variabel, di butuhkan oleh seluruh bahasa pemrograman tak terkecuali.
- Pemilihan tipe data Jika suatu bahasa pemrograman hendak digunakan memerlukan deklarasi variabel, perlu diperhatikan dalam memilih tipe data.

- Harga instruksi kebanyakan intruksi mempunyai kegunaan dan fungsi yang sama, namun tiap-tiap intruksi juga memiliki kekurang dan kelebihannya masing-masing.

- Aturan sintaks ketika menulis suatu program maka akan di pergunakanlah aturan sintaks pemrograman ini untuk memudahkan.

- Tampilan hasil ketika menulis suatu algoritma tampilan output yang nantinya akan di sajikan tidak akan terlihat. Poin teknik ini diperhitungkan ketika mengubahnya kedalam sebuah program.

- Teknik mengoperasikan compiler 6 . atau interpreter $\sim$ Bahasa pemrograman yang akan dipergunakan dalam penulisan algoritma akan termasuk dalam kelompok compiler atau interpreter.

Menguasai Cara Memprogram dan Bahasa Pemrograman

mempelajari cara memprogram tidak akan serupa dengan mempelajari bahasa pemrograman. Belajar memprogram merupakan belajar mengenai metodologi penanganan suatu masalah, setelah itu menerapkannya pada suatu notasi yang mudah dibmengerti dan di pahami. Sedangkan mempelajari bahasa pemrograman di situ kira akan di latih memakai bahasa sekaligus tata aturan bahasanya, perintah-perintah atau deklarasinya, dan juga teknik menjalankan compiler-nya, dan menggunakan fungsi dari perintah-perintah maupun deklarasi tersebut ke dalam pembuatan program yg 
penulisannya hanya menggunakan bahasa itu saja. Sampai sekarang ini tersedia puluhan bahsa pemrograman, antara lain bahasa rakitan (assembly), Fortran, Cobol, Ada, PL/I, Algol, Pascal, C, C++, Basic, Prolog, LISP, PRG, bahasabahasa simulasi seperti CSMP, Simscript, GPSS, Dinamo.

Menurut fungsi pakainya, bahasa pemrograman bisa dikelompokkan atas dua bagian besar:

- Bahasa pemrograman tujuan khusus. yang tergolong ke dalam kelompok ini adalah Cobol (aplikasi bisnis dan administrasi). Fortran (komputasi ilmiah terapan), bahasa assembly (pemrograman mesin terapan), Prolog (kecerdasan buatan terapan), bahasa simulasi, dan sebagainya .

- Bahasa pemrograman tujuan umum,

Bisa di manfaatkan fungsinya pada berbagai aplikasi. Yang tergolong dalam kelompok ini yaitu bahasa Pascal, Basic dan C. Tentu saja pembagian ini tidak kaku. Bahasa tujuan khusus tidak berarti tidak dapat digunakan untuk aplikasi lain. Cobol, misalnya, juga dapat digunakan untuk aplikasi ilmiah, tetapi kemampuannya terbatas. Jelas, bahasa pemrograman yang berbeda dikembangkan untuk aplikasi yang berbeda.

Disesuaikan dengan apakah notasi bahasa pemrograman lebih "dekat" dengan bahasa mesin atau manusia, bahasa pemrograman dikelompokkan menjadi dua jenis:

- Bahasa tingkat rendah

Jenis bahasa ini diciptakan untuk memudahkan komputer langsung menangkap instruksi dan langsung di kerjakan, dan tidak lagi di bawa ke translator untuk di terjemahkan. Bahasa mesin bisa kita ambil sebagai contoh. Instruksi yang ada di memori di ambil oleh CPU kemudian secepat mungkin memahaminya agar selanjutnya segera melakukan operasi. Primitif, ini lah sifat dari bahasa tingkat rendah, sederhana, lebih berorientasi pada mesin, dan manusia tidak mudah mengerti dan memahaminya. Dan bahasa assembly notasinya terbilang dekat dengan bahasa mesin makanya di golongkan kedalam kelompok ini, walaupun ketika komputer ingin melakukan operasi hendaknya terlebih dahulu di terjemahkan dulu ke dalam bahasa mesin.

- Bahasa tingkat tinggi

Bahasa ini cenderung berorientasi pada bahasa inggris yaitu lebih manusiawi dan hal ini yang menjadikan lebih mudahnya memahami suatu pemrograman. Namun, komputer tidak mampu secara langsung menjalan kan perintah pada program dalam bahasa tingkat tingi, hendaknya terlebih dulu di bawa ke penerjemah bahasa untuk di terjemahkan(disebut compiler) ke dalam bahasa mesin sebelum dieksekusi oleh CPU. Contoh bahasa tingkat tinggi adalah Pascal, PL/I, Ada, Cobol, Basic, Fortran, C, C++, dan sebagainya.

Beberapa syarat agar menjadi algoritma yang baik adalah:

- Tingkatan kepercayaan (reliability) yang tinggi. Output yang di hasikan dari proses hendaknya memiliki akurasi yang tinggi dan benar.

- Hendaknya suatu pemrosesan yang di lakukan bersifat efisien (biaya rendah). Hendaknya frekuensi yang di pergunakan harus singkat dan di selesaikan mungkin secepatnya. 
- Umum. Cenderung ke dalam menyelesaikan suatu kasus yang bersifat umum, dan tidak hanya satu kasus yang terselesaikan.

- Dapat diperluas (expandable). Itu harus menjadi hal yang bisa di perluas secara lanjut dan di kembangkan namun di sesuaikan dengan aturan atau syarat yang ada .

- Mudah dipahami. Siapa pun nantinya yang akan membaca, si pembaca dapat mengerti algoritme yang Anda buat. Sulitnya memahami suatu program akan mempersulit pemeliharaan (manage).

- Portabilitas tinggi (portabilitas). Dapat diimplementasikan dengan sangat mudah di seluruh platfrom komputer.

- Precise (benar, benar, teliti). Seluruh perintah (instruksi) hendaknya di buat dengan hati-hati dan tanpa raguragu, agar selanjutnya di terapkan tanpa ada bagian secara eksplisit suatu instruksi tersebut.

Sebelum melakukan suatu pemrograman mari lihat tahapan-tahapan yang harus di lakukan dalam Pemrograman

Berikut step by step yang perlu di lakukan dalam penyelesaian suatu program dalam komputer:

\section{* Definisikan Masalah}

Disini kita akan di tuntun agar mengetahui beberapa hal yang akan membuat kita tahu bagaimana permasalahan tersebut untuk di analisis, hal-hal itu sebagai berikut : - Input atau kondisi awal yang tersedia - Output atau hasil akhir yang diinginkan - Beberapa data yang sudah teraedia atau data lain yang sudah di sediakan.

- Operator yang sudah sedia.
- Syarat atau beberapa masalah atau biasa di sebut kendala yang nantinya akan di pecahkan.

* Buat Algoritma dan Struktur Cara Penyelesaian

Jika suatu kendala atau masalah yang hendak di pecahkan bersifat kompleks, hendaknya di buat ke dalam beberapa modul. Seringkali pada proses tahapan penyusunan algoritma selalu di awali terlebih dahulu dari tahap yang bersifat global. Langkah-langkah yang bersifat global tersebut akan di perhalus hingga nantinya akan menjadi langkah yang lebih detail dan rinci nantinya. Bagi masalah yang bersifat komplek akan sangat efisien jika menggunakan pendekatan ini pada proses pembuatan algoritma. Dalam penghalusan tahapan ini kita akan melakukan pemecahan tahapan hingga menjadi beberapa langkah. Kemudian langkah-langkah yang sudah di pecah di uraikan kembali sehingga membentuk beberapa lanfkah sederhana. Sampai semua tiap-tiap langkah sudah menjadi rinci dan tepat maka penghalusan akan terus berlanjut hingga cukup dan bisa di laksanakannya suatu proses oleh pemroses.

\section{Menulis Program}

Setelah pembuatan suatu algoritma sudah selesai, maka selanjutnya akan di lakukan penenerjemahan dari suatu bahasa komputer sampai menjadi sebuah program. Dan salah satu hal yang paling penting harus di perhatikan yaitu pemilihan algoritma agar programnya bekerja dengan baik, karena jika salag memilih algoritma maka kinerja program akan menjadi kurang baik. Perhatikan standar penilaian suatu program yang baik sebagai berikut: 
a. Standar teknik pemecahan masalah

- Teknik Top-Down

Merupakan Teknik pemecahan masalah yang paling umum digunakan. konsepnya adalah dengan membagi suatu masalah kompleks ke dalam beberapa kelompokkelompok masalah yang kecil. Kemudian setelah terbagi menjadi kelompok-kelompok kecil maka di lakukanlah analisis. Jika masih memungkinkan akan di bagi kembali ke dalam subbagian-subbagian dan kemudian akan di rancang lah tahapantahapan untuk penyelesaian yang lebih detail.

\section{- Teknik Bottom-Up}

Prinsip teknik bottom up ini mempunyai strategi pemecahan masalah dengan cara penggabungan seluruh prosedur yang ada hingga membentuk suatu program, hal ini di lakukan untuk penanganan masalah tersebut agar mudah untuk ke tahap pemprograman.

b. Standar penyusunan program

- logika dan penulisan bersifat fakta dan benar adanya.

- hitungan minimal waktu yang di habiskan pada penulisan program.

- Tingkat Kecepatan maksimum eksekusi program

- Ekspresi pemakaian memori.

- mudah sulitnya perawatan dan
pengembangan suatu program.

- User Friendly.

- Portability.

- Pemrograman modular.

* Temukan Kesalahan

- Kesalahan dalam penulisan suatu program (sintaks).

- Menerapkan kesalahan: semantik, logika dan akurasi.

* Uji dan Verifikasi Program
Pertama yang harus di lakukan yaitu pengujian bisakah di jalankannya suatu program. Apabila ada kendala untuk menjalankan suatu program tersebut maka perbaikilah terlebih dahulu sintaksnya, namun ketika suatu program bisa di jalankan maka lanjutkan dengan pengujian menggunakan data biasa merupakan data yang di harapkan oleh sistem. Exampel data ekstrim, misal suatu program membutuhkan input jumlah data namun pengguna memasukkan angka yang negatif. Maka harus di lakukan pengujian program yang relatif besar jumlahnya.

* Dokumentasi Program

Ada dua macam pembagian Dokumentasi program, yang terdiri dari dokumentasi eksternal dan dokumentasi jnternal. Adapun suatu pembuatan dokumentasi di dalam suatu program di sebut dokumentasi internal, yang apabila setiap kali seseorang menulis baris program, di dalam instruksinya harus memuat komentar agar kita mudah mengingat logika yang termuat dalam instruksi, hal tersebut akan berguna ketika kegiatan pengembangan program akan di laksanakan. Sedangkan suatu pendokumentasian yang di lakukan di luar program di sebut dokumentasi eksternal, berupa pembuatan panduan pengguna atau manual untuk memudahkan kita dalam menjalankan suatu program dan aturannya.

* Pemeliharaan Program

- perbaikilah setiap kekurangan yang telah di temukan.

- Modifikasi, karena perubahan spesifikasi.

\section{Hasil dan Pembahasan}

pada aktivitas yang biasa kita ulang ulang setiap harinya ada beberapa alur yang diekspresikan dalam suatu algoritma. Cara memasak nasi goreng atau beberapa masakan yang terdapat pada sebuah buku 
resep bisa juga di sebut sebagai algoritma. Dalam setiap ide masakan maka akan ada pula urutan langkah pembuatannya masakan tersebut. Ketika suatulangkah yang di kerjakan tidak logis, hidangan yang diinginkan tidak akan bisa diproduksi. Sebelum melakukan suatu trik memasak yang baru biasanya ibu-ibu akan membaca dengan teliti langkah demi langkah kemudian melakukan kegiatan masaknya sesuai instruksi yang telah di bacanya. Secara menyeluruh (umum), pihak (objek) yang melakukan pekerjaan disebut pengolah (prosesor). Prosesor dapat berupa human, komputer, robot, atau perangkat elektronik lainnya. Prosesor mengerjakan suatu proses dengan mengeksekusi atau "mengeksekusi" algoritma yang menggambarkan proses tersebut.

Algoritma adalah gambaran dari pola perilaku primitif, yaitu tindakan yang sebelumnya didefinisikan dan dinyatakan sebelumnya bahwa tindakan tersebut dapat menyebabkan kejadian. Eksekusi bekerja pada langkah-langkah dalam algoritma. Prosesor mengerjakan proses bersesuai pada suaty algoritma yang diterapkan padanya. Si juru masak me numis bawang sesuai dengan resep yang di terimanya, pianis memainkan lagu di papan, bukan balok. Oleh sebab itu pemilihan algoritma harus sesuai dalam bentuk yang mudah di pahami oleh prosesor, sehingga prosesor harus:

- Paham seluruh tahapan yang termuat dalam algoritma.

- Pengerjaan suatu operasi di lakukan sesuai dengan tahapan tersebut.

Suatu algoritma memuat prosedur tahapan-tahapan pemecahan suatu masalah. Dapat di simpulkan bahwa algoritma adalah proses prosedural. Dalam pemrograman prosedural, program di bagi lagi dalam dua bagian berupa bagian data dan bagian instruksi. Dalam bagian intruksi terdapat instruksi berurutan yang telah di eksekusi bagian demi bagian oleh prosesor. Percabangan bersyarat dapat mengubah suatu alur eksekusi instruksi. Instruksi yang berurutan mampu memanipulasi sebuah data yang tersimpan pada memori. Para ahli mengatakan bahwa pola sekuensial di ikuti oleh eksekusi program. Paradigma suatu pemrograman semacam ini memerlukan pemrograman prosedural. Bahasa tingkat tinggi seperti Cobol, Basic, Pascal, Fortran, dan $\mathrm{C} / \mathrm{C}++$ yang bekerja untuk mendukung kegiatan prosedural, oleh sebab itu dibutuhkan pula bahasa prosedural. Selain paradigma pemrograman prosedural, terdapat paradigma lain yaitu pemrograman berorientasi objek (Object Oriented Programming atau OOP). Paradigma pemrograman ini adalah tren baru dan sangat populer akhir akhir ini. Dalam paradigma OOP, instruksi dan data dienkapsulasi menjadi satu. Unit ini digelar sebagai kelas dan turunan dari kelas saat run-time disebut objek. Data dari suatu objek hanya bisa diakses dengan instruksiinstruksi yang termuat dalam objek tersebut. Paradigma pemrograman lainnya berupa pemrograman fungsional, pemrograman deklaratif, dan pemrograman konkuren.

Komputer berperan sebagai pemroses. Agar komputer mampu melaksanakannya, suatu algoritma hendaknya kita tulis terlebih dahulu ke dalam notasi bahasa pemrograman agar nantinya bisa terbilang sebagai suatu program. Maka dapat di simpulkan bahwa program merupakan wujud teknis atau implementasi yang berasal dari algoritma di tuliskan sesuai dengan bahasa pemrograman yang sudah di tentukan sebelumnya sehingga komputer mampu melakukan eksekusinya.

Kata "algoritma" dan "program" sering digunakan secara bergantian. Misalnya, seseorang mengatakan sesuatu seperti ini:"program pengurutan data menggunakan algoritma pengurutan seleksi". Atau 
pertanyaan seperti ini: "Bagaimana algoritma dan programnya?

gambarkan grafiknya?". Jika Anda sudah mengerti dalam hal algoritma yang disebutkan sebelumnya, Anda dapat membedakan arti dari kata algoritma dan program.

Algoritma merupakan suatu tahapantahapan pemecahan dari suatu masalah, dan suatu realisasi dari algoritma pada suatu bahasa pemrograman di sebut suatu program. Penulisan suatu program di buat pada salah satu bahasa programan dan proses pembuatan suatu program tersebut di sebut sebagai pemrograman. Si penulis program di panggil sebagai programer. Semua langkah-langkah dalam program disebut instruksi atau pernyataan. Maka dari itu, bisa kita simpulkan bahwa suatu program terdiri dari serangkaian instruksi. Ketika sebuah pernyataan/instruksi dieksekusi, maka yang melakukan operasi yang bersesuaian dengan instruksinya di ambil alih oleh komputer. Menurut garis besar, komputer terdiri dari empat komponen utama, yaitu perangkat input, perangkat output, unit pengolah utama, dan memori. Unit pemroses utama (Central Processing Unit - CPU) merupakan "otak" komputer, yang di gunakan untuk menjalankan operasi dasar sama halnya dengan operasi perbandingan, operasi kalkulasi, operasi baca, dan operasi tulis.

Memori merupakan bagian yang berguna dan di manfaatkan sebagai pengingat atau penyimpanan. Apa pun yang di taruh ke dalam penimpanan/memori merupakan suatu program (memuat operasi yang akan dikerjakan oleh CPU) dan data atau informasi (sesuatu yang proses operasi). Perangkat input dan output (I/O devices) adalah suatu petangkat yang menyimpankan data atau yang menaruh data pada memori, berguna juga sebagai alat komunikasi untuk mengkomunikasikan hasil aktifitas (outputnya) oleh komputer. Contoh perangkat input termasuk keyboard, pemindai, dan disk. Contoh perangkat output adalah display (monitor), printer (printer), dan disc.

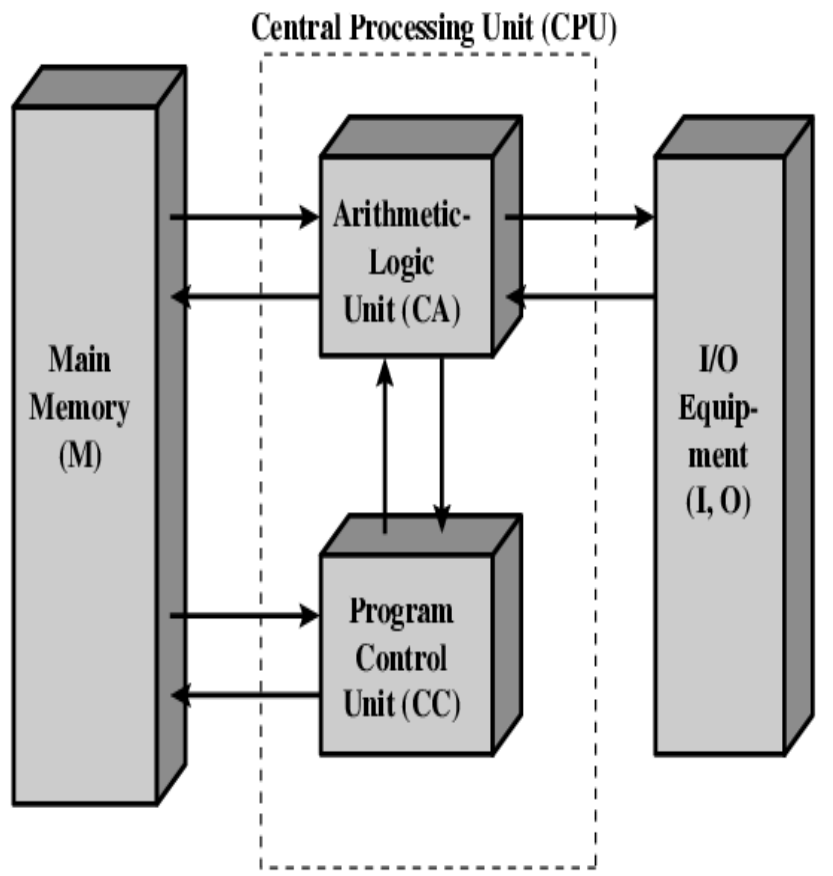

Mekanisme atau cara kerja empat komponen di atas bisa di paparkan sebagai berikut. Pertama-tama itu program masukkan lah ke dalam panyimpanan/memori komputer. Ketika program dijalankan (execute), tiaptiap pernyataan atau instruksi yang tadinya telah di simpan pada memori di kirimlah ke CPU. Maka dari situ CPU bakalan mengerjakan operasi yang bersesuaian dengan intruksi yang sudah di berikan tadi. Dan pada waktu membutuhan data pada saat operasi, maka di situlah suatu data bakalan di baca dari perangkat input, suatu data itu di simpankan ke dalam memori untuk selanjutnya di kirim ke CPU di gunakan ketika operasi membutuhkannya. Pada saat proses mendapatkan output atau informasi, output disimpan dalam memori, kemudian memori menulis output ke perangkat output (misalnya dengan menampilkannya di layar monitor).

\section{Kesimpulan}


Algoritma merupakan titik tengah dari ilmu komputer atau informatika. Bisa di bilang tidak sedikit cabang ilmu komputer yang tertuju pada terminologi algoritma. Dalam kehidupan sehari-hari terdapat banyak proses yang diekspresikan dalam suatu algoritma. Algoritme merupakan gambaran pola tingkah laku yang di tetapkan secara primirif, berupa tindakan yang didefinisikan dan diberi sebutan, dan dianggap bahwa tindakan ini dapat dilakukan untuk menyebabkan suatu peristiwa. Mengeksekusi suatu algoritma artinya melakukan tahapan-tahapan dalam algoritma.

Suatu Program merupakan wujud teknis atau implementasi dari suatu algoritma yang penulisannya sesuai dengN bahasa pemrograman tertentu hingga nantinya suatu komputer mampu melakukan eksekusi. Mempelajari suatu pemrograman berarti kita belajar mengenai metodologi suatu pemecahan masalah kemudian di tekakkan menggunakan notasi tertentu yang tingkat kemudahan membacanya dan pemahamannya tinggi .

\section{Daftar Bacaaan}

[1] Munir, Rinaldi. "Algoritma dan Pemrograman, Jilid I". Bandung : Informatika. 2007

[2] Bagus, Kadek dan Tristha udayana .2018 "Penerapan Komponen dan Struktur Algoritma Pada Algoritma dan Pemrograman Dasar". Jurnal Bisnis dan Teknologi Politeknik.vol.5,No.1.

[3] Maulana, Gun Gun. 2017."Pembelajaran Dasar Algoritma dan Pemrograman Menggunakan El-Goritma Berbasis web". Jurnal Teknik Mesin. Vol.6No.2.

[4] Suryadi," Algoritma dan Pemrograman", Penerbit Gunadarma,
Jakarta, 1997

[5] Yuhendra, "Bahan Ajar Terseleksi Algoritma dan Pemrograman", Institut Teknologi Padang, 2013

[6] Samsudin, Irawan dan Sri Mulyani. 2020."Perancangan Sistem Informasi Pembelajaran Algoritma dan Pemrograman Verbasis Web Pada Program Studi Teknik Informatika STMIK ERESHA". Jurnal Informatika. Vol.5, No.4.

[7] Retta, Allen Marga , Asnurul isroqmi dan Tika Dwi Noprianti. 2016."Pengaruh Penerapan Algoritma Terhadap Pemrograman Komputer". Jurnal Inovasi Matematika. Vol.2,No.2.

[8] Nata, "Logika dan Pemrograman Komputer", Teknik Mesin Udayana, 2012

[9] Mariz Arief Tria, "Komputer dan Dasar Pemrograman", Politeknik Negeri Bandung, 2010

[10] Naufal, Mohammad Farid . 2018."Analisis Teknik Pemvelaharan dan Pengajaran Pemrograman Pada Universitas dan Industri". Jurnal Informatika dan multimedia".vol.10,No.2.

[11] Isroqmi, Asnurul. 2017 . "Kemampuan Mahasiswa Memahami Logika Pemrograman Komputer Melalui Algoritma".Jurnal Pendidikan Matematika .vol.2,No.2

[12] Julianto, Ahmad Kamal Asri dan Ekohariadi . 2020."Metode Gamication Pada Pemrograman Dasar Teknik Komputer dan Informatika di Sekolah Menengah Kejuruan". Jurnal IT-EDU.vol.5,No.1, Hal: 77-84. 